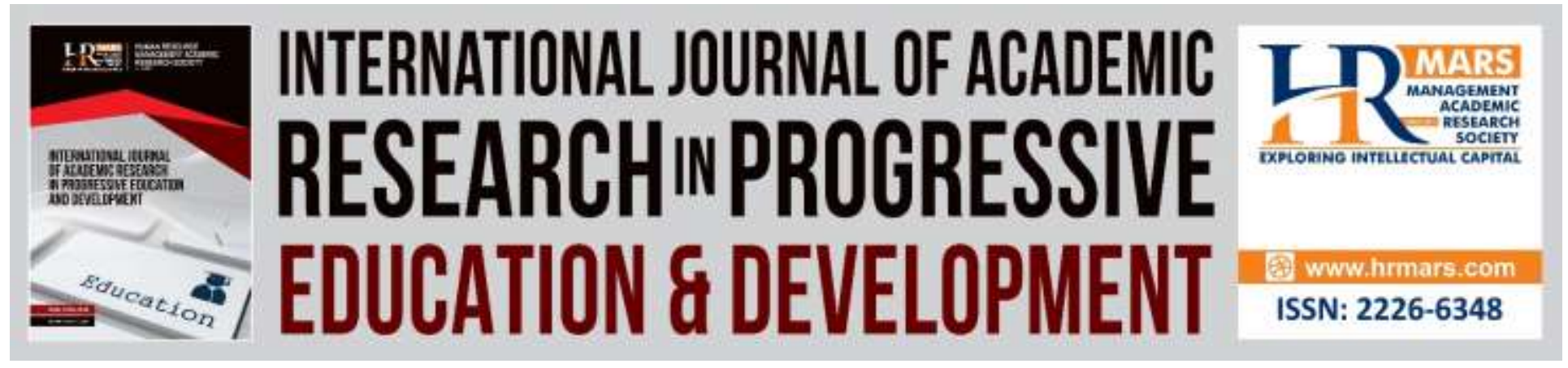

\title{
Parental Behaviors as a Risk Factor Associated with Delinquency among High School Students
}

\author{
Noor Lela Ahmad, Atikah Amidi
}

To Link this Article: http://dx.doi.org/10.6007/IJARPED/v8-i4/6906

DOI:10.6007/IJARPED/v8-i4/6906

Received: 19 October 2019, Revised: 30 November 2019, Accepted: 11 December 2019

Published Online: 30 December 2019

In-Text Citation: (Ahmad \& Amidi, 2019)

To Cite this Article: Ahmad, N. L., \& Amidi, A. (2019). Parental Behaviors as a Risk Factor Associated with Delinquency among High School Students. International Journal of Academic Research in Progressive Education and Development, 8(4), 1074-1091.

Copyright: (C) 2019 The Author(s)

Published by Human Resource Management Academic Research Society (www.hrmars.com)

This article is published under the Creative Commons Attribution (CC BY 4.0) license. Anyone may reproduce, distribute, translate and create derivative works of this article (for both commercial and non-commercial purposes), subject to full attribution to the original publication and authors. The full terms of this license may be seen

at: http://creativecommons.org/licences/by/4.0/legalcode

Vol. 8(4) 2019, Pg. 1074 - 1091

http://hrmars.com/index.php/pages/detail/IJARPED

JOURNAL HOMEPAGE

Full Terms \& Conditions of access and use can be found at http://hrmars.com/index.php/pages/detail/publication-ethics 


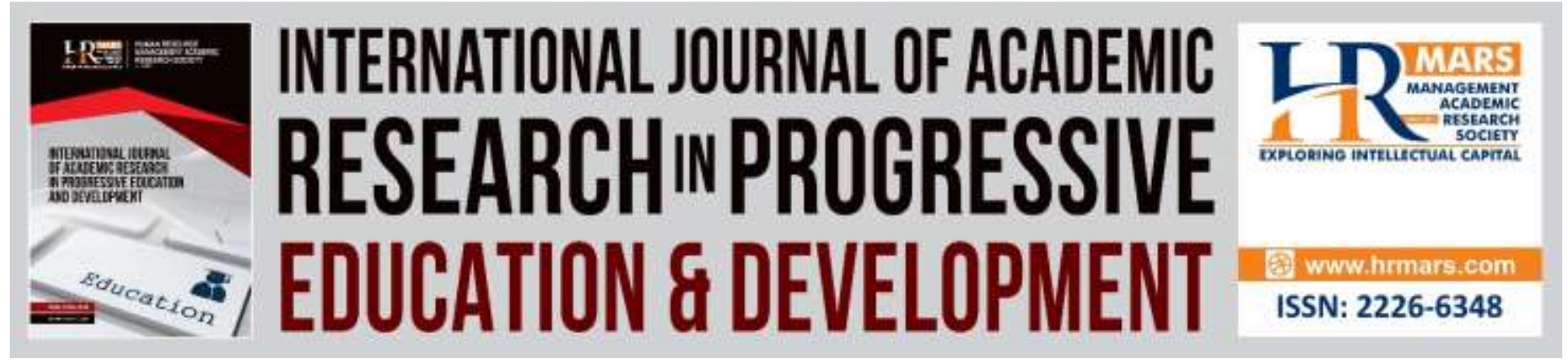

\title{
Parental Behaviors as a Risk Factor Associated with Delinquency among High School Students
}

\author{
Noor Lela Ahmad, Atikah Amidi \\ Sultan Idris Education University, Malaysia
}

\begin{abstract}
The purpose of this study is to identify parent's behavior and their influence on the tendency of students behaving delinquently. This research was conducted among 86 high school students in three public high schools in Gombak area, Selangor. Samples were chosen based on their records of disciplines and were high risk youths in their school because of behaviors problem. Three types of parent's behavior, which are, verbal behaviors, physical behaviors and anti-social behaviors were assessed to determine their influences on the student's delinquency such as violent behaviors, abused and general delinquency such as skipping school for no reason. The result showed that there was no significant association between parent's behaviors with student's delinquency. However, findings indicated that several items in parent's physical behavior (e.g. father is a fierce man) and verbal behavior (e.g. parents always nags me about my behaviors) have moderate link and contribute to the delinquent outcomes of the students. This results demonstrated that several parenting behavior have negative impact on teenagers. Furthermore, anti-social behavior scored low in association with student's delinquent behaviors. The findings revealed that parent's behaviors are not the main risk factor that contributes to the student's delinquent behaviors but other external factors such as friends, media and environment experiences might associated to student's delinquent attitudes thus need more further research in this area.
\end{abstract}

Keywords: Delinquency, Behaviors, Parents, Youth, Students

\section{Introduction}

Adolescence is the period where teenager's transit from childhood to adulthood and time where they keep exploring themselves and the environment. This time is also called as period of stress and periods of increase autonomy (Harris-McKoy and Cui, 2013). During these periods teenagers attend high schools, choosing their own friend, developing themselves and is regarded as the most important and critical time of their life (Hoeve et al., 2009). Teenagers will go through crisis with the change of their physical and emotional state at this stage of life (Klein et al., 2012; Fatimah, 2007). Their emotions are constantly disturbed and in order to fit into the society, they 
will make an effort to fulfill the expectations that families and society have towards them (Valois, 2014).

On the other hand, in the midst of emotional disturbance, there is no doubt that there is a possibility that they will be swayed and choose the path which will lead them to social issues. Because of this, teenagers should be given the opportunity to grow and develop themselves (Steinberg and Silk, 2002). At the range of 12 to 18 years old, teenagers are still not fully mature and need of parent attention and guidance (Steinberg and Silk, 2002). This suggests that parent's roles are critical thus need parents to look back on their parenting behavior in order to lean their children towards the positive side (Smetana et al., 2005; Fuziah et al., 2009). Therefore the role of parents, school and community are crucial in providing guidance and potentially can contribute to teenager's positive behavior (Valois, 2014). In reality, the attitudes of today's teenagers also raise the concerns of the society on the problems that are affecting them. Consciously, in today's cyber age, social problems have increased and tapered (Shetgiri, 2013; Hamidah, Zawawi and Rorlinda, 2013). If back in the old day, we often hear that teenager delinquent behavior usually occurred in the cities or urban areas, today however, such problems are also often heard happening in rural areas such as in Feldas and villages (Badrulzaman, 2006).

Aggressive behavior is the behavior that consists of physical or verbal behavior that threatens with harming others (Haslinda et al., 2015). Delinquents are aggressive behaviors or actions that break the norms of society done by teenagers but if they are adult they are referred to as deviants (Rathakrishnan, 2011; Qureshi, 2011; Valois, 2014). In general, teenagers are categorized as delinquents because they are still enrolled in high schools (Tibang Pegari, 2013). In school institutions however, boys or girls that engage in physical and verbal aggression are more known as those with discipline problems (Pegari, 2013; Zainal, 2014). This study attempts to add to literature by further explored parent's behavior which are verbal behaviors, physical behaviors and anti-social behaviors by further examined their associations on the student's delinquency such as violent behaviors, drug used and abused. This study suggests that parent's role and parenting behavior needs to be further explored to seek greater understanding in this area.

\section{Student Delinquency}

Based on the analysis of a research done by Institute for Youth Research Malaysia (2010), 92 per cent of the research respondents, which equals to about 2249 of 2403 total respondents, have done at least one anti-social behavior. Further a study by Puzzanchera (2008), reported that 2.11 million juvenile arrests were made among youth under 18 year old in 2008 . However, studies found that majority of delinquent teenager do not become career criminals in their future life (Mulvey, 2011; Modecki et al., 2014). Data from Pittsburgh Youth Study which consisted of male respondent between the age of 6-20, and researcher following them for a period of 14 years revealed that $60 \%$ of them not commit to delinquent act or non-serious delinquent act over those 14 years (Hoeve et al., 2008). However, Mulvey (2011) in the Pathways to Desistance study that followed serious juvenile offenders at the age 14-18 over seven years reported that half of those considered serious offenders continued to commit serious delinquent act into adulthood. 
Several studies have demonstrated that teenager's delinquent behaviors can be categorized as a behavioral disorder (Modecki et al., 2014; Nurhidayati, 2011; Murray and Farrington, 2005). According to Valois (2014) behavioral disorder is divided into three specifications. The first is considered as a lightweight specification where aggressive behaviors shown by the teenager does not contribute to a bigger problem such as lying, skipping school or coming home late at night (Turner, 2013; Azizi et al., 2011). The second specification is that the delinquency behavior is at moderate level where the actions are in between light and heavy such as stealing and vandalizing properties but not harming other people (Hoffman et al., 2016). The third specification is an aggressive behavior which can also contribute to risky outcomes such as self-destructive, harming others and other parties getting injured. Forced sex, robberies, crimes involving weapons are some of the examples of behaviors in the third specification category (Shetgiri, 2013; Hoffman et al., 2016; Luk et al., 200; Badrulzaman, 2006).

Due to teenagers demanding need of attention, parenting behaviors, parental control and responsiveness are needed for better outcomes for children (Harris-McKoy and Cui, 2012). Children behavioral act need guidance as they are still quite immature and are prone to risky behavior (Barnes et al., 2006). Scholars in psychology argued that spoiling, erratically or harshly are some disciplining techniques used by parents of delinquent teenagers (Marcotte, Marcotte and Bouffard, 2001; Patterson and Yoerger, 2002). Parents who use punishment excessively on their children instead of giving explanations on their unacceptable behaviors may cause them to act delinquently (Hoeve et al., 2009; Abdorreza and Razumah, 2010). The same goes to parents who are inconsistent in handling their children anti-social and pro-social behaviors as it can exposed them to delinquent behaviors (Murray and Farrington, 2005; Suzana, 2012; Ahmad, Amidi and Wahid, 2018).

There are four aspects of family interaction that has a close relationship with delinquent teenagers (Azizi et al., 2012; Hoeve et al., 2009). The first aspect is that there are very little numbers of house rules within the family. Low interaction among family unit may cause social problem and academic functioning (Aaron and Dallaire, 2010). Secondly, parents themselves lack monitor and pay little attention to the teenager's behaviors (Patterson and Yoerger, 2002). Harris-McKoy and Cui (2012); Dimitris, (2015) argued that lack of parental control had a positive association with children delinquency. Thirdly, parents are inconsistent in educating their children. Inconsistency in educating children might confuse them on what is supposed to be the right behavior and what is not (Abdorreza and Razumah, 2010). Lastly, parents lack the knowledge of handling problematic teenagers and family crisis which then leads to not finding the right solution to it (Azizi et al., 2012).

When analyzing literature further, studies found that lacks of religious knowledge and family's attention can also lead them to engage in aggressive behavior (Munir, Saharizah and Misnan, 2015; Khadijah et al., 2012; Ahmad, Amidi and Ab Wahid, 2018). In fact, religious knowledge was associated with delinquency (Munir, Saharizah and Misnan, 2015). Apart from failing to get enough religious education from the parents, the actions of delinquent teenagers 
are also seen to be effected by negative behaviors shown by the parents (Suzana, 2012). Having a problematic family is also one of the factors that cause the students to have problems being disciplined and act delinquently (Badrulzaman, 2006). The development of a teenager is highly influenced by his or her environment, thus parent guidance and monitoring is crucial and important for teenagers to accommodate teenager's development (Ahmad, 2015; Ahmad, Amidi and Ab Wahid, 2018; Klein et al., 2012). Not surprisingly, in a research conducted by Khadijah et al., (2012) showed that student's with negative behavioral problem comes from problematic family background. On one hand, children that come from problematic family are more likely to drop out school (Trice and Brewster, 2004). On the other hand, bad parenting behavior by parents is associated with higher rates of delinquency and more likely to be arrested (Murray and Farrington, 2005). The literature suggested that parents role are very important and parents have the responsibility to provides shelter and define teenager's personality as well as to equip them a healthy psychological state of mind (Abd. Razak and Norani, 2011).

Several studies demonstrated that supportive and positive parents are negatively linked to delinquency (Aaron and Dallaire, 2010; Hoeve et al., 2009; Klein et al., 2012; Khadijah et al., 2012). This indicates that parenting behavior with high levels of support and warmth are linked to low level of delinquency behavior and better outcomes among children (Aaron and Dallaire, 2009). Some researchers suggest that good parental control could prevent teenagers from establishing aggressive behavior (Smetana, 2005). Unfortunately, our hectic and busy lifestyles have brought trouble and problems into our family's life. Parents are the most to be blamed whenever their teenagers are involved in negative social issues (Patterson and Yoerger, 2002). In some places, even parents are penalized in courts for the delinquency act by their children (Hoeve et al., 2009). This is because parents are responsible and play an important role in shaping the attitude and behavior of their children (Ahmad, 2015). The child's positive or negative self conducts is dependent on the parenting role of the parents (Munir, Saharizah and Misnan, 2015). Thus, parenting styles are an important ways that can be used by parents to support, monitor, influence and control their children and can be used to assess the quality of parental behavior (Rohner, 2004).

Besides, there are many reports through social media regarding teenager's delinquent and criminal behavior, which have now become news often heard on a day to day basis (Akmal, Mahzan, and Razaq, 2016). In fact, these issues prove that teenagers today are facing some serious social problems. News reported on their mischievousness has also raised concerns and worries to the society. According to Yahaya et al., (2007) delinquency cases that are most heard of is cases that happens in boarding schools. Such cases lead to parents being worried about sending their child to a boarding school. However, such cases are also likely to happen at any other regular high school. School boards are also affected and their credibility in instilling good moral and values to the students are also doubted (Peter et al., 2012; Ahmad, 2015).

In relation to that, Sharif and Suria, (2012) stated that although many suggestions have been made to solve student's discipline problems in school, sadly, efforts to implement the suggestions ends only at the discussion table. Campaigns and programs done in school are only 
effective on a small number of students (Azizi, Halimah and Hasan, 2011). This has also been discussed by Buerah, Shanah and Hamimah (2015) who stated that although rules are implemented in school, delinquent behaviors are still seen in both high school and primary school students. Based on statistics of total number of high discipline cases, many of the students who skip schools miss out on the lesson which then leads their academic performances to deteriorate (Hairi, Azmi, and Shazili, 2012). Social issues are one of the main challenges students face to excel in school (Fatimah, 2007). In contrast, several studies have demonstrated that majority of teenagers who excel in their academic have a clean record of discipline at school (Leai, 2002; Khadijah, 2015; Hairi, Azmi, and Shazili, 2012). Meanwhile, teenagers who exposed with high conflict and discipline problems however, have records of declining academic performances (Fatimah, 2007).

In fact, studies on student's delinquency have also shown that the higher student's academic performances are, the lower the amount of social wrongdoings will be (Khadijah, 2015; Zabedah, 2005). Literature showed that individuals with high intelligence also tend to have the same level of emotional intelligence (Zabedah, 2005). Therefore, this obviously showed that person with emotional intelligence can be seen through their moral intention (Hamidah, Zawawi and Rorlinda, 2013). This exhibited that individuals that showed good moral values and manners intend to have good emotional intelligence. Moreover, emotional intelligence has a significant relationship in shaping teenager's moral values (Khadijah, 2015). Apart from that, emotional intelligence is highly needed in educational development so that it advances the achievement of the teenagers.

In today's family institution, it is common for both parents to have their own individual careers. Hence, challenges faced by parents with careers are in terms of balancing work pressure and paying attention to their family (Saat, 2011). If the parents failed to overcome such challenges, it may lead to the collapse of their family institution (Khadijah et al., 2012). Azizi et al., (2010) explained that students often involve themselves in physical fights because they have either witnessed their parents quarrelling or if they themselves are victims of physical abuse at home. In this case, it can be concluded that individuals that have once been a victim of physical abuse may possibly grow up to be more aggressive and violence that can threaten and harm others. Thus, family conflict is one of the risk factor that contributes to teenager's delinquency and necessary to examine how family behavior can influence teenager's functioning.

In conclusion, teenagers especially those enrolled in schools are the group of people who may easily be influenced by their environment and their parent's behavior. As the closest people in their life, parent's and family support plays an important role in shaping teenagers personality (Smetana, 2005). In short, teenagers grow up in accordance to how their families shape them and parental control is crucial for teenagers for positive outcomes (Steinberg and Silk, 2002). Study on the association between parent behavior and children delinquency could give some knowledge on how to prevent delinquency. Hence, the purpose of this research is to identify the behavioral characteristics of delinquent teenager's parents and explore whether parental behavior was related and may lead to teenagers in high school to act delinquently. 


\section{Method}

This study is a survey-based descriptive research and adopt questionnaire to collect data. Descriptive research explains situations or relationships between variables (Noraini, 2010; Newman, 2012). A total of 86 samples were identified based on their record of disciplines and were high risk youth in their school in the area of Gombak, Selangor. Purposive sampling technique was used as a sampling method to collect data (Zikmund et al., 2013). The selection of schools in this area were based on the statistics that showed high discipline cases among students in the school in this district compared to other districts in Selangor, the schools also were in distressed neighborhoods and experienced rapid urban development. According to David et al., (2013) the selection of samples should display the population and can be generalized. The instrument employed was a self-administrative questionnaire and was adapted and modified from Parental Behavioral Inventory (PBI) by Schaefer (1968) and 'Paulson's Perception of Parenting Scale' by Paulson (1994).

The questionnaire consisted of four sections namely demographics data, physical behavior characteristics, verbal behavior characteristics and anti-social behavior characteristics. Respondents are required to response to the best answer based on 5-point Likert Scale ( $1=$ strongly disagree to $5=$ strongly agree) on the question asked related to physical behavior characteristics, verbal behavior characteristics and anti-social behavior characteristics. Data collected were analyzed using descriptive statistics to address the value of mean, frequencies and percentage. Inference statistics using Pearson's Correlation was used to test the hypothesis and answering research questions. The Cronbach' alpha coefficient analysis was undertaken and the reliability result were between $0.701-0.850$, which demonstrated that the reliability of the items were good and acceptable (Pallant, 2013).

\section{Data Analyses and Results Demographic Information}

Table 1 demonstrated the demographic detail of the respondents according to gender, elective subject taken and school location. All respondents were selected from art stream courses in their school. Finding demonstrated that $65.1 \%$ of the respondents are male and $34.9 \%$ of the respondents are female and indicated that majority of delinquency students were male. Analysis of the findings from elective subject shows that $14.0 \%$ of the respondents are those who studies accounting, $10.5 \%$ are those who study Information and Communications Technology, $29.1 \%$ are those who studies literature, and $46.5 \%$ are those who studies business. Almost $66.3 \%$ of the students attend school in urban area while $33.7 \%$ attend schools in rural areas. 
INTERNATIONAL JOURNAL OF ACADEMIC RESEARCH IN PROGRESSIVE EDUCATION AND DEVELOPMENT

Vol. 8, No. 4, 2019, E-ISSN: 2226-6348 @ 2019 HRMARS

Table 1: Descriptive Statistics on Respondents Demographic Profile

\begin{tabular}{lcc}
\hline Variables & Number (N) & $\begin{array}{c}\text { Percentage } \\
(\%)\end{array}$ \\
\hline 1. Gender & 56 & 65.1 \\
Male & 30 & 34.9 \\
Female & 86 & 100 \\
Total & & \\
2. Elective Subject & 12 & 14.0 \\
Accounting & 9 & 10.5 \\
Information and & & \\
Communication Technology & 25 & 29.1 \\
Literature & 40 & 46.1 \\
Business & 86 & 100 \\
Total & & \\
Urban & 57 & 66.3 \\
Rural Area & 29 & 33.7 \\
Total & 86 & 100 \\
\hline
\end{tabular}

\section{Parents' and Guardians' Highest Level of Education}

As shown in Table 2, 48.8\% of respondents' fathers, $53.3 \%$ of respondents' mothers and $3.5 \%$ of respondents' guardians have at least Malaysian Examination Certificate (MEC) as their highest level of education. About $12.8 \%$ respondents reported that their parents had a diploma and other $8.2 \%$ reported that their parents had a university degree.

Table 2: Descriptive Statistics on Parents and Guardians Highest Level of Education.

\begin{tabular}{lcccccc}
\hline \multirow{2}{*}{$\begin{array}{l}\text { Highest Level of } \\
\text { Education }\end{array}$} & \multicolumn{2}{c}{ Father } & \multicolumn{3}{c}{ Mother } & \multicolumn{2}{c}{ Guardian } \\
\cline { 2 - 7 } & $\begin{array}{c}\text { Number } \\
(\mathrm{N})\end{array}$ & $\begin{array}{c}\text { Percentage } \\
(\%)\end{array}$ & $\begin{array}{c}\text { Number } \\
(\mathrm{N})\end{array}$ & $\begin{array}{c}\text { Percentage } \\
(\%)\end{array}$ & $\begin{array}{c}\text { Number } \\
(\mathrm{N})\end{array}$ & $\begin{array}{c}\text { Percentage } \\
(\%)\end{array}$ \\
\hline Degree & 3 & 3.5 & 4 & 4.7 & 0 & 0 \\
Diploma & 6 & 7.0 & 5 & 5.8 & 1 & 1.2 \\
STPM & 4 & 4.7 & 5 & 5.8 & 0 & 3.5 \\
SPM & 42 & 48.8 & 46 & 53.5 & 3 & 3.5 \\
SRP/LCE & 17 & 19.8 & 10 & 11.6 & 0 & 0 \\
Standard 6/ & 8 & 9.3 & 9 & 10.5 & 2 & 7.0 \\
Primary School & & & & & & 0 \\
Does not attend & 0 & 0 & 1 & 1.2 & 0 & 0 \\
school & & & & & & 6 \\
\hline Total & 80 & 93.0 & 80 & 93.0 & 6 & 7.0 \\
\hline
\end{tabular}

\section{Parents' and Guardians' Occupation}

In Table 3, summarizes the occupation of respondent's parent and guardian. Findings indicated that $23.0 \%$ of respondent's father works in private sectors, $19.8 \%$ of them are self-employed 
INTERNATIONAL JOURNAL OF ACADEMIC RESEARCH IN PROGRESSIVE EDUCATION AND

DEVELOPMENT

Vol. 8, No. 4, 2019, E-ISSN: 2226-6348 @ 2019 HRMARS

while $50.0 \%$ of respondent's mothers are unemployed. The other $3.5 \%$ are guardians who work in government sectors.

Table 3: Descriptive Statistics on Parent's and Guardian's Occupation.

\begin{tabular}{lcccccc}
\hline \multirow{2}{*}{ Occupation } & \multicolumn{2}{c}{ Father } & \multicolumn{2}{c}{ Mother } & \multicolumn{2}{c}{ Guardian } \\
\cline { 2 - 7 } & $\begin{array}{c}\text { Number } \\
(\mathrm{N})\end{array}$ & $\begin{array}{c}\text { Percentage } \\
(\%)\end{array}$ & $\begin{array}{c}\text { Number } \\
(\mathrm{N})\end{array}$ & $\begin{array}{c}\text { Percentage } \\
(\%)\end{array}$ & $\begin{array}{c}\text { Number } \\
(\mathrm{N})\end{array}$ & $\begin{array}{c}\text { Percentage } \\
(\%)\end{array}$ \\
\hline Government & 11 & 12.8 & 9 & 10.5 & 3 & 3.5 \\
Private & 20 & 23.3 & 9 & 10.5 & 0 & 0 \\
Factories & 8 & 9.3 & 4 & 4.7 & 1 & 1.2 \\
Labourers & 16 & 18.6 & 0 & 0 & 2 & 2.3 \\
Self-Employed & 17 & 19.8 & 5 & 5.8 & 0 & 0 \\
Business & 5 & 5.8 & 10 & 11.6 & 0 & 0 \\
Unemployed & 3 & 3.5 & 43 & 50.0 & 0 & 0 \\
\hline Total & 80 & 93.0 & 80 & 93.0 & 6 & 7.0 \\
\hline
\end{tabular}

\section{Parental Behaviors}

Findings on the characteristics of the parent's behaviors are divided into three sections namely physical behaviors, verbal actions and anti-social behaviors.

Table 4: Descriptive Statistics of Parent Physical Behaviors Characteristics

\begin{tabular}{|c|c|c|c|c|}
\hline \multirow[b]{2}{*}{ Parents Physical Behaviors } & \multicolumn{3}{|c|}{ Frequencies (\%) } & \multirow[b]{2}{*}{ Mean } \\
\hline & Low & $\begin{array}{l}\text { Moderat } \\
\text { e }\end{array}$ & High & \\
\hline Father is a fierce man & $18(21.0)$ & $32(37.2)$ & $36(41.9)$ & 3.27 \\
\hline $\begin{array}{l}\text { Father always uses physical violence when } \\
\text { quarrelling with my mother }\end{array}$ & $79(91.8)$ & $5(5.8)$ & $2(2.3)$ & 1.38 \\
\hline $\begin{array}{l}\text { Parent always punish me even when I make } \\
\text { small mistakes }\end{array}$ & $57(66.3)$ & $20(23.3)$ & $\begin{array}{l}180 \\
(77.4)\end{array}$ & 2.12 \\
\hline Father smoke cigarettes in front of me & & & & 2.99 \\
\hline Parent beat me up when I make mistakes & $34(39.6)$ & $13(15.1)$ & $39(45.4)$ & 2.52 \\
\hline Parent take other people's belongings & $44(51.2)$ & $21(24.4)$ & $21(24.4)$ & 1.57 \\
\hline without permission & $71(82.5)$ & $11(12.8)$ & $4(4.7)$ & \\
\hline Total Mean & & & & 2.31 \\
\hline
\end{tabular}

Note: Low 1-2.33, Moderate 2.34-3.66, High 3.67-5.00

The results summarized in Table 4 demonstrated parent physical behavior characteristic of delinquent student. Findings indicated that delinquent student father is a fierce man stated the highest mean of 3.27 and exhibit moderate level of physical behavior. A total of $41.9 \%$ of the respondents agree of this statement. The other two items that exhibit moderate level of parent physical behavior were father smoke cigarettes in front of me and parent beat me up when I make mistakes. When looking within each item it can be observed that three item namely, father always uses physical violence when quarrelling with my mother, parent always punish me even 
Vol. 8, No. 4, 2019, E-ISSN: 2226-6348@ 2019 HRMARS

when I make small mistakes and parent take other people's belongings without permission displayed low levels of physical behavior characteristics. Overall, the result for physical behaviors of the parents of delinquent students showed an overall mean of 2.31 for six items. Findings revealed that the characteristic of physical behaviors among parents of delinquent students affects student's behavior at low level.

Table 5: Descriptive Statistics of Parent Verbal Behaviors Characteristics

\begin{tabular}{|c|c|c|c|c|}
\hline \multirow[b]{2}{*}{ Parent Verbal Behaviors } & \multicolumn{3}{|c|}{ Frequencies (\%) } & \multirow[b]{2}{*}{ Mean } \\
\hline & Low & $\begin{array}{l}\text { Moderat } \\
\mathrm{e}\end{array}$ & High & \\
\hline Parents always nags about my behavior & $3(3.5)$ & $10(11.6)$ & $73(84.8)$ & 4.17 \\
\hline $\begin{array}{l}\text { Parents are always quarrelling and doesn't } \\
\text { respect to each other }\end{array}$ & $58(67.4)$ & $20(23.3)$ & $8(9.3)$ & 2.09 \\
\hline $\begin{array}{l}\text { Parent is always speaking ill of others } \\
\text { (neighbors'/family relatives) }\end{array}$ & $68(79.1)$ & 15 (17.4) & $3(3.5)$ & 1.74 \\
\hline Parent swears when she/he is angry & $55(66.3)$ & $19(22.1)$ & $\begin{array}{l}10 \\
(11.7)\end{array}$ & 2.09 \\
\hline Parent likes to lie & $76(88.4)$ & $10(1.6)$ & 0 & 1.38 \\
\hline Total mean & & & & 2.30 \\
\hline
\end{tabular}

Note: Low 1-2.33, Moderate 2.34-3.66, High 3.67-5.00

The findings presented in Table 5 displayed the verbal behaviors characteristics among parents of delinquent students. The results indicated that high levels of verbal behavior comes from only one item where the statement parent always nags me about my behaviors (84.4\%) is the most agreed response from the respondents as it obtained the highest mean of 4.17 compared to other statements. However the rest of the listed parent verbal behavior exhibit low levels of verbal behavior whereas the mean obtained were 1.38 to 2.09 . Overall, the findings of the characteristics of parent's verbal behaviors showed a record of a total mean of 2.30 for five statements. Data revealed that parent verbal behaviors reported low level of impact on the student's delinquent behaviors. 
INTERNATIONAL JOURNAL OF ACADEMIC RESEARCH IN PROGRESSIVE EDUCATION AND DEVELOPMENT

Vol. 8, No. 4, 2019, E-ISSN: 2226-6348@ 2019 HRMARS

Table 6: Descriptive Statistics of Parent Anti-Social Behaviors Characteristics

\begin{tabular}{|c|c|c|c|c|}
\hline \multirow[b]{2}{*}{ Parent Physical Behaviors } & \multicolumn{4}{|c|}{ Frequencies (\%) } \\
\hline & Low & $\begin{array}{l}\text { Moderat } \\
\text { e }\end{array}$ & High & n \\
\hline Parent always comes late at night & $55(64)$ & $21(24.4)$ & $10(11.6)$ & 2.19 \\
\hline Parent involved in crime & $85(98.8)$ & $0(0)$ & $1(1.2$ & 1.13 \\
\hline Parent takes drugs and alcohol & 85 (98.9) & $1(1.2)$ & $0(0)$ & 1.09 \\
\hline My father has another girlfriend & $85(95.3)$ & $1(1.2)$ & $3(3.5)$ & 1.23 \\
\hline $\begin{array}{l}\text { My father loves spending times at a coffee } \\
\text { shops/restaurants }\end{array}$ & 67 (77.9) & $11(12.8)$ & $8(9.3)$ & 1.81 \\
\hline My father always breaks the law when & $72(83.8)$ & $11(12.8)$ & $3(3.5)$ & 1.56 \\
\hline My father loves to gamble (betting/lottery) & $82(95.3)$ & $2(2.3)$ & $2(2.3)$ & 1.23 \\
\hline Parent keeps/watches pornographic films & $78(90.7)$ & $6(7)$ & $2(2.4)$ & 1.31 \\
\hline Parent dislike socializing with the society & $58(67.4)$ & $24(27.9)$ & $4(4.6)$ & 1.94 \\
\hline Total mean & & & & 1.50 \\
\hline
\end{tabular}

Note: Low 1-2.33, Moderate 2.34-3.66, High 3.67-5.00

Table 6 above shows the characteristics of parent anti-social behaviors. All the items in parent anti-social behavior scored low exhibit that the characteristics of anti-social behaviors of the parents of delinquent students have low impact on the actions of delinquent students. Overall, the findings of the characteristics of parent's verbal behaviors showed a record of a total mean of 1.50 for nine statements.

Table 7: Descriptive Statistics of Students Delinquency Behaviors

\begin{tabular}{ll} 
Student Delinquency Behaviors & Mean \\
\hline Physical Behavior & 1.57 \\
Verbal Behavior & 2.03 \\
Anti-social Behavior & 1.59 \\
Sexual Behavior & 1.22 \\
\end{tabular}

Note: Low 1-2.33, Moderate 2.34-3.66, High 3.67-5.00

The descriptive statistic presented in Table 7 summarizes the levels of delinquency behaviour among respondent. Findings revealed that although the sample consisted of high-risk students with discipline issues in school, majority of them scored low in all four delinquent behaviour dimensions. 
INTERNATIONAL JOURNAL OF ACADEMIC RESEARCH IN PROGRESSIVE EDUCATION AND

DEVELOPMENT

Vol. 8, No. 4, 2019, E-ISSN: 2226-6348@ 2019 HRMARS

Hypothesis Testing

Association of Parental Behavioral Characteristics and Student Delinquency

Table 8: Relationship between Parental Behavioral Characteristics and Students Delinquency

\begin{tabular}{llcc}
\hline & & Parental Behavior & Students Delinquency \\
\hline \multirow{2}{*}{ Parent's } & Pearson Correlation & 1 & .056 \\
Behavior & Sig. (2-tailed) & & .611 \\
& $\mathrm{~N}$ & 86 & 86 \\
\hline Delinquent & Pearson Correlation & .056 & 1 \\
Student's & Sig. (2-tailed) & .611 & \\
Behavior & $\mathrm{N}$ & 86 & 86 \\
\hline
\end{tabular}

Correlation is significant at the 0.05 level (2-tailed).

Table 8 demonstrated Pearson Correlation analysis on the significant association between parental behavioral characteristic and student delinquency behavior. The finding reported the value of $p=0.611>0.05$. The result indicated that there is no significant relationship between student's delinquency and the behaviors of their parents.

\section{Discussion}

The current study examines parent's behavior characteristic of delinquent students and to explore the associations between parental behavior characteristic and student delinquency. A total of 86 respondents were selected for this research, included were $65.1 \%$ male students and $34.9 \%$ female students from three respective schools in Gombak, Selangor. The selections of schools in this area were based on the statistics that showed high discipline and aggressive cases among students. The schools were located in both urban and rural areas and were in distressed neighborhoods and experienced rapid urban development. The selected respondents are from four different electives art stream courses namely Accounting, Information and Communication Technology, Literature and Business. Respondents were chosen based on their records of disciplines and were high risk youths in their school because of aggressive and delinquent behaviors. The study showed that majority of respondents with $80.3 \%$ respondents, lives with their parents. A total of $1.2 \%$ of the respondents lives with his/her father, while $8.2 \%$ lives with their mother and the remaining $10.5 \%$ lives with their guardian.

Parent behaviors were divided into three characteristics namely, physical behaviors, verbal behaviors and anti-social behaviors. The parent's physical behaviors obtained a mean of 2.31 , and according to the value of mean scores, the results indicated that the characteristics of the parent's physical behaviors are low. However, looking precisely within items, the statement 'my father is a very fierce man', 'my father smoke cigarettes in front of $m e^{\prime}$ and 'my mother/father beat me up when I make mistakes' obtained a total mean of 3.27, 2.99 and 2.52 respectively. These three items of parent physical behaviors were associated with moderate level of student's delinquent behavior. Thus, results suggested that parent physical behavior is an important risk factor associated with teenager's delinquent behavior. In line with Mahzan (2007) the results indicated that children learn through mimicking the behaviors of their parents as the parents are individuals that are the closest to them. The facts that parent are the role model of 
the family and when parent show bad behavior, for an example when parent smoke in front of their children, it encourages them to engage in negative action following their parent's behavior.

According to Yahaya et al., (2007), teenagers today often show impoliteness and their courtesy is decreasing. Amongst the factors found are due to the parent's lack of attention on the behaviors of their children and elders not setting a good example on the teenagers especially the students. As for Ge et al., (1996), argued that parents who are uncaring and lack of disciplinary skills is a predictor for the appearance of delinquency. In short, findings reflect that parents should exhibit a positive image to their children and instill good values into the family. Study by Harris-McKoy and Cui (2013) pointed out that there was significant association between lack of parental control and children delinquency concurrently in teenager and longitudinally into young adulthood. Previous study found out that parental role is essential in developing positive outcome for their children (Baumrind, 2005; Steinberg and Silk, 2002; Nelson et al., 2011). Thus, study implies that parents should continue to control over their children behavior and decision because they really need guidance from parent to alleviate risky behavior that may lead them to criminal act.

In terms of the parent's verbal behaviors, five questions were asked and the total mean obtained were 2.30. The fact that parent verbal behaviors were low might be due to the fact that they know their responsibility as a parent to teach good values to their children. However, when looking within each parent verbal behavior it can be observed that one statement 'my mother always nags about my behaviors' reported high level of verbal behavior associated with student delinquency. The finding indicate that parent's constant nagging and lack of advice might cause the children to feel bored to stay at home and find other place to hang out. The effect of parent delinquency will make the children are at high risk to engage with youth crime if meet the wrong person or friend outside of their home (Aaron and Dallaire, 2010). Parent always wants the best for their children and therefore must change the way they teach and serve as a good role model to them. Saat (2011) suggested that parent must not only teach their children to be well in behavior, but should also be disciplined themselves in order to be a good example and can influence divine values to their children.

According to a research by Zainuddin \& Norazmah (2011), parents who often acts negatively such as quarrelling, will cause the environment of the house to become rather gloomy and disturbing. The parents quarrel at home disturbs the children's state of emotion. Hence, they will feel uncomfortable and stressed to stay at home. The parent's behaviors, such as quarrelling, using physical violence, and many more, will also be copied by the children. Other than that, Arieff Salleh and Wardah (2006), emphasized that parent's quarrelling will also give an impact on the children's emotion. Parents who quarrel in front of their children will cause the children to stay away from them. However, their action might then leads to high possibility to engage in crime or aggressive behavior. According to Munir, Saharizah and Misnan (2015), when children make mistakes, parents should approach them through giving advices and never use physical violence on them. Advice should not be given through nagging. Physical violence and constant 
nagging leads them to act aggressively towards their parents and as a result, they end up repeating the same mistake (Hairi, Azmi and Shazili, 2012).

The findings reveal that anti-social behaviors of the parent are low. Amongst the three aspects of behaviors, anti-social behaviors scored the lowest mean. Moreover, looking precisely into each item, all of the statements under anti-social behaviors scored mean below 1.50, which means that parent anti-social behaviors have low association with children delinquency in this study. The statement 'my father always comes home late at night' scored the highest mean at 2.19. The possibility of the father coming home late at night could due to his career or otherwise his hobby of hanging out with friends. However, according to Akmal, Mahzan and Razaq (2016), parents who are too busy working and constantly neglects spending time with their children causes the children to seek attention elsewhere. Neglected children and chaotic family are some of the many reasons why children behave delinquently (Aaron and Dallaire, 2010).

As stated by Shamsaadal and Abdullah (2006), a child behaving delinquently is for the purpose of getting their parent's attention. They felt as if the attention given by their parents are decreasing compared to when they were younger. Parents therefore, should care more about their children's problems and development, and prevent them from behaving delinquently. The result of a research done by Prinzie et al., (2012); Yin, Yusof, Lok, \& Zakariya, (2018); Desfitrina (2018), stated that children's personality has a big relationship with their parent's personality. In other words, the behaviors of the children signify the behaviors of both the parents. The finding of this research shows that there is no significant association between the actions and behaviors of the parents with the possibility of the students acting or behaving delinquently. One of the reason of this finding might be the respondent in this study were not youth that committed in high risk crime but they are students that have discipline cases in school. The findings of this study exhibit that the characteristics of parent's behaviors give low effect on the behaviors of delinquent students. Thus, further research need to be conducted in other area in Malaysia and investigate other factors that influence youth to behave aggressively.

\section{Summary}

The research findings showed that the frequency of the students behaving delinquently is low. The most dominant type of delinquent behavior is verbal behaviors which are done orally. Teenagers often lie to their parents, friends and others as well. Overall, delinquent students only behave at a moderate level of delinquent behaviors. Only a few teenagers acts on serious delinquent actions and commit crimes such as taking drugs and pills, trespass school and shops and stealing. The findings also showed no associations between parent's behaviors and student's delinquency, but suggest that parent's roles are crucial and important to decreasing aggressive behavior of young teenagers. The results imply that there are other factors that might contribute to teenagers delinquency behaviors. Further studies that include more variables as the potential predicting factors toward student's delinquent attitudes are suggested. Therefore, research findings left an impact on the significant influence of parents on the student's manners and courtesy. The findings suggest that parents are advised to set a good example and become a role model to their children. Besides, a proper parental control accompanied by religious teachings is 
important throughout the children's development. This study contributed in several aspects. It enriches the literature by exploring factors that associate with delinquency and provides suggestions to parents in developing good parental behavior to get better outcomes for children.

\section{References}

Kordi, A., and Baharudin, R. (2010). Parenting attitude and style and its effect on children's school achievements. International Journal of Psychological Studies, Vol. 2(2). 217-222.

Ismail, A. M., Salleh, S. M., and Jemali, M. (2015). Analisis bentuk didikan ibu bapa bagi membentuk sahsiah cemerlang: kajian di Sekolah Menengah Kebangsaan Pulau Sebang, Alor Gajah, Melaka. Jurnal Perspektif. Jilid. 8 Bil. 2. 1-10.

Salleh, A. R. Z. D. N. M. (2011). Konteks keluarga dan hubungannya dengan penglibatan ibu bapa dalam pendidikan anak-anak di sekolah menengah. Jurnal Pendidikan Malaysia. Vol. 36(1). 35-44.

Aaron, L., and Dallaire, D. H. (2010). Parental incarceration and multiple risk experiences: effects on family dynamics and children' delinquency. Journal Youth Adolescence. Vol. 39(12). 1471-84.

Ahmad, N. L. (2015). Integrating ethics into accounting curriculum: Overview from accounting educators. Malaysia Journal of Society and Space. Vol. 11. Issue 6.pp. 87-97.

Ahmad, N. L., Amidi, A., \& Ab Wahid, H. (2018). The influence of parent on the delinquent behavior among secondary school students. Journal of Humanities, Culture and Business. Vol. 2, No. 8. pp. 85-94.

Mokhtar, A. S. R. D. W. (2006). Membentuk jati diri remaja. Bentong: PTS Professional Publishing Sdn. Bhd.

Yahaya, A. (2010). Persepsi perlakuan agresif dan faktor yang mempengaruhi di lima buah sekolah kawasan bandar Johor Bahru. Jurnal Teknologi. Vol. 53 (Sains Sosial). Universiti Teknologi Malaysia, Skudai, Johor.

Yahaya, A., Ramli, J., Muhamad, A. L. A. D. Z. (2007). Buli. Universiti Teknologi Malaysia: Johor.

Yahaya, A., Omar, Halimah M. D. M. H. (2011). Permasalahan yang mempengaruhi pembelajaran dan pencapaian akademik pelajar bumiputra (tingkatan 4) di sekolah menengah teknik di Johor Bahru. Journal of Educational Psychology and Counseling. Vol 2. Jun 2011. 1-27.

Yahaya, A., Hashim, S., Boon, Y., Azizi, J. R. D. N. E. (2012). Penyelewengan tingkah laku remaja: punca dan rawatan. UTM press: Universiti Teknologi Malaysia.

Baharom, B. (2006). Persekitaran keluarga dan kesannya terhadap tingkah laku devian remaja di daerah Pontian, Johor. Laporan Tesis ljazah Sarjana Pendidikan (Psikologi Pendidikan). Universiti Teknologi Malaysia.

Rathakrishnan, B. (2011). Devian sosial. Universiti Malaysia Sabah.

Tunggak, B., Ngadi, S., \& Naim, H. A. (2015). Delinkuen pelajar dan penyelesaiannya menerusi model pembangunan sahsiah remaja/ pelajar muslim bersepadu. Jurnal Hadhari. Vol. 7(2) (2015). 11-30.

Cohen, L., Manion, L., \& Morrison, K. R. B. (2007). Research methods in education. Routlege.

David, M., Levine, T. C., Krehbiel, \& Mark, L., Berenson. (2013). Business Statistics. Pearson Education Limited: England 
Ismail, F. A., Ahmad, M. M. A. D. A. R. (2016). Buli dan gangsterisme di sekolah. International Conference on Education and Regional Development: Indonesia.

Ali, F. (2007). Masalah sosial pelajar dan hubungannya dengan kemerosotan pembelajaran. Jurnal Usuluddin, Bil 25 (2007). 145-154.

Shaffie, F., Yusoff, N., Sakdan, M. F., Saad, S., Abdullah, W. A. R. K. W., Zubir, A., Fadzillah, Azizan, H. D. M. S. A. (2009). Profil Remaja Berisiko Tinggi. Universiti Utara Malaysia: Kedah.

Ge, X., Best, K. M., Conger, R. D., \& Simon, R. L. (1996). Parenting behaviours and the occurrence and co-occurrence of adolescent depressive symptoms and conduct problems. Development Psychology, 32(4), pp. 717-731.

Sulaiman, H., Yusof, Z. I. D. R. (2013). Kecerdasan emosi menurut Al-quran dan Al-sunnah: Aplikasinya dalam membentuk akhlak remaja. Journal of Islamic Education. June 2013, Vol. 1 Issue 2. 17-30.

Harris-McKoy, D., \& Cui, M. (2013). Parental control, adolescent delinquency and young adult criminal behaviour. Journal of Children Family Study. Vol. 22, pp. 836-843.

Hoeve, M., Blokland, A., Dubas, S. J., Loeber, R. Gerris, J. R. M., \& Laan, V. D. P. H. (2008). Trajectories of delinquency and parenting styles. Journal of Abnormal Child Psychology. Vol. 36, pp. 223-235.

Hoffman, J. P., Erickson, L. P., Spence, K. R. (2013). Modelling the association between academic achievement and delinquency: an application of interactional theory. Vol. 51(3). 629-660.

Malaysian Institute of Youth Research. (2010). Tingkah laku delinkuen.

Murray, J., \& Farrington, D. P. (2005). Parental imprisonment: Effects on boys' antisocial behaviour and delinquency through the life-course. Journal of Child Psychology and Psychiatry. Vol. 46, pp.1269-1278.

Jaafar, J. L. S. (2012). Psikologi remaja dan masalah-masalah psikososial. Pearson Malaysia Sdn Bhd: Selangor.

Razak, K. M. (2015). Solat dan hubungannya dengan pendidikan. Jurnal Teknikal Dan Sains Sosial. Bilangan 5 Jilid 1 Jun 2015. 16-24.

Alavi, K., Nen, S., Ibrahim, F., Akhir, N. M., Mohamad, M. S., Nordin, N. M. (2012). Hamil luar nikah dalam kalangan remaja. Journal of Social Sciences and Humanities. Vol. 7, Number 1, 131140, April Special- 2012.

Zainal, K. (2014). Pengurusan disiplin pelajar sekolah. Universiti kembangsaan Malaysia: Selangor.

Luk, J. W., Wang, J., and Simons-Morton, B. G. (2010). Bullying victimization and substance use among US adolescents: mediation by depression. Prevention Science. Vol. 11. 355-359

Arshad, M. (2007). The role of parents in providing education to children at early age. Majalah Pendidikan, Vol. 30(2). 129-136.

Marcotte, G., Marcotte, D., and Bouffard, T. (2002). The influence of familial support and dysfunctional attitudes on depression and delinquency in an adolescent population. European Journal of Psychology of Education. Vol. 17(363).

Jamil, M. S. M. D. S. A. (2012). mengenal pasti punca punca masalah ponteng di kalangan pelajar sekolah rendah: satu kajian kes. Journal of Educational Psychology \& Counseling. Vol. 6, June 2012. pp. 50-73. 
Mulvey, E. (2011). Highlights from pathways to desistance: A longitudinal study of serious adolescent offenders. Office of Juvenile Justice and Delinquency Prevention NCJ 230971.

Omar, N. H., Manaf, A. A., Ayob, D. A. S. (2012). Pengujian model gaya keibubapaan Baumrind ke atas pencapaian akademik pelajar sekolah menengah. Journal of Sosial Sciences and Humanities. Vol. 7, Num. 1. 105-120, April Special.

Idris, N. (2010). Penyelidikan dalam pendidikan. Malaysia: McGraw-Hill (Malaysia) Sdn. Bhd. Pallant, J. (2013). SPSS survival manual. Mc Graw Hill: England.

Prinzie, P., Dekovic, M., Alithe, L., Akker, V. D., Amaranta, D., Haan, D., Sabine, E. M. J. S. Hendriks, A. A. J. (2012). Fathers' personality and its interaction with children's personality as predictors of perceived parenting behaviour six years later. Journal of Personality and Individual Differences. Vol. 52, 183-189.

Ibrahim, R. I. D. N. (2007). Faktor-faktor mempengaruhi keterlibatan remaja dalam perlumbaan motorsikal haram dan hubungannya dengan jenis personaliti, sokongan sosial dan coping skill. Laporan Akhir Penyelidikan: Universiti Kebangsaan Malaysia.

Sulaiman, S. (2011). Tip menjadi ibu bapa mithali, Selangor : PTS Millennia Sdn. Bhd.

Sulaiman, S. S. D. A. (2006). Konflik remaja masa kini dan cabaran menanganinya. Kolej Universiti Teknologi Tun Hussein Onn.

Smetana, J., Crean, H. F., \& Campione-Barr, N. (2005). Adolescents' and parents' changing conceptions of parental authority. New Directions for Child and Adolescent Development. Vol. 108, pp. 31-36.

Steinberg, L., \& Silk, J. S. (2002). Parenting adolescents. In M.Bornstein (Ed.)., Handbook of parenting children and parenting. Vol. 1, pp. 103-133. Mahwah, NJ: Lawrence Erlbaum.

Nurhidayati, T. (2011).Pendekatan Kasih Sayang: Solusi pengembangan karakter terpuji dan akhlak mulia dalam diri anak didik. Jurnal Falasifa. Vol. 2 No.2. September 2011.

Trice, A. D., \& Brewster, J. (2004). The effects of maternal incarceration on adolescent children. Journal of Police and Criminal Psychology. Vol. 19, pp. 27-35.

Ab.Razak, Z. (2005). Hubungan gaya pembelajaran dengan kecerdasan emosi dan pencapaian akademik. Tesis Sarjana Pendidikan. Universiti Kebangsaan Malaysia, Bangi.

Roslan, Z. S. D. N. M. (2011). Faktor-faktor yang mempengaruhi remaja terlibat dalam masalah sosial di Sekolah Tunas Bakti, Sungai Lereh, Melaka. Journal of Education Psychology \& Counseling. Vol. 1 Mac 2011, 115-140.

Yin, K. Y., Yusof, R., Lok, S. Y. P., \& Zakariya, Z. (2018). The Effects of Collaborative Mobile Learning Using Edmodo among Economics Undergraduates. International Journal of Academic Research in Progressive Education and Development, 7(3), 40-47.

Ahmad, N. L., \& Amidi, A. (2019). Parental Behaviors as a Risk Factor Associated with Delinquency among High School Students. International Journal of Academic Research in Progressive Education and Development, 8(4), 977-994.

Dimitris, K. (2015). THE INFLUENCE OF FAMILY ON ADOLESCENTS' USE OF LEISURE. Multilingual Academic Journal of Education and Social Sciences, 3(1), 17-25.

Desfitrina. (2018). The Influence, Gender, Life on Development Planning in Indonesia, International Journal of Academic Research in Accounting, Finance and Management Sciences 8 (3): 255-264. 
INTERNATIONAL JOURNAL OF ACADEMIC RESEARCH IN PROGRESSIVE EDUCATION AND DEVELOPMENT

Vol. 8, No. 4, 2019, E-ISSN: 2226-6348 @ 2019 HRMARS

\section{Corresponding Author}

Noor Lela Ahmad

Sultan Idris Education University

Email: noor.lela@fpe.upsi.edu.my 